\title{
RELIABILITY THE UTILIZATION FROM WATER OPERATING UNIT
}

\author{
Shrien F. A.*
}

\section{ABSTRACT}

This research aims to increase the maximizing used of water unit management in the Egyptian countryside, by connecting roasting unit with power source of waterwheel irrigation, and used the thermal energy that found in the exhaustting gasses as a source undirectly in grains roasting. And modify turnning unit to receipt the motion from transmission system of watewheel instead of electric motor. Study the effecting of different roasting temperature on moisture content and discoloration some grains (cowpea -bean). This system saved the consumed energy by $83.11 \%$ and saving the operational costs by $78 \%$ comparing to use roasting unit only or waterwheel only. Added to that the roasting process was increased the period keep of grains.

\section{INTRODUCTION}

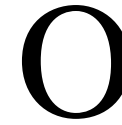

ut of the interaction of scientific research with the environment and the role of scientific research in the service of society has been identified one of the problems facing the rural home. A damage of some grains as a result of high humidity such grains leads to damage both by insects or mold so the pesticides were using to maintain them without damage, but these pesticides have an adverse effect on humans and the environment. To take advantage of some of the resources available in the rural environment, waterwheel irrigation by hyphenation roasting unit with power source of waterwheel, and used the thermal energy, this found in the exhaust engine as a source indirectly in the roasting of grains. El-Awad and Stillwater (1991) found that waterwheels with curves conforming to the Archimedes spiral were geometrically similar. This led to normalized characteristic curves for four and six bucket wheels that can be using to estimate the discharge per revolution, rapidly in the field, from a few easily measured parameters. The relative benefits of this method compared to flumes were discussing.

\section{*Agric. Eng. Res. Institute, Dokki, Giza, Egypt.}


In addition, the mechanical efficiencies of eleven field installations were determined with values ranging from $22 \%$ to $54 \%$. The sources of inefficiency were also discussing. Bruce (1992) and Ruf (1996) indicated that the full account of the development of Egyptian irrigation up to the present day. It is in the present day that the Egyptian farmers (fellahs) are facing the problem of the breakdown in traditional water management practices. Pumps are replacing water wheels (saqia). The extra power available to pump owners has resulted in considerable water management problems. Additionally, as responsibility for management was devolving from farmers' organizations and state services, such organizations are in danger of running down. This might leave an anarchic situation. Zaghloul and Mourad (1996) designed experiments about simulate the traditional ash-storage procedure, adopted by the Egyptian farmers, it was found that a ratio of one part of ash to one part of cowpea seeds reduced the rate of infestation from $70 \%$ in the untreated seeds to $14.80 \%$ in the ashtreated seeds after a strange period of eight months. Similarly, the loss in the seeds weight was also reducing from $50.50 \%$ in the control to $10.50 \%$ in the treated seeds. For comparison, atelic $2 \%$ dust, used in a separate treatment, was more effective against the insect pest than the ash-treated seeds. Yang et al. (1997) measurement the specific heat of borage (Borago officials) seeds at temperature ranges from 6 to $20^{\circ} \mathrm{c}$ and moisture content from 12 to $30.3 \%$ (w.b.) using the differential scanning calorimetric procedure. The result showed that, specific heat was ranging from 0.77 to $1.99 \mathrm{~kJ} / \mathrm{kg}^{\circ} \mathrm{k}$. Irtwange and Igbeka (2002) reported that, most of processing operation for agricultural products involves the addition and removal of heat. Many gains and seeds were subjecting to disposal of the consumer. The thermal process may include heating, cooling, roasting and freezing. The rate of addition and removal of heat was determining by the thermal properties of the products. Measurement of thermal conductivity is therefore important owing to its application for processing and storage. Specific heat capacity is one of the most important thermal properties of a material related to heat transfer characteristics. This parameter is essential in study heating, dry and cooling processes for cereal seeds. Mousa et al (1998) found that the wheat grown beside the road-contained lead as 10 times of those at distance more than $100 \mathrm{~m}$ in the wheat plants, despite of high lead accumulation was founding in roots. Shrein et al. (2007) studied the 
effecting of waterwheel transmission system by adding gearbox instead of the traditional system. The developed system decreases the consumed energy and saving in the operational costs comparing to the traditional waterwheel transmission system.

\section{The aims of this research were:}

1- Increased the efficiency of power source of water wheel.

2- Reduce the rate of contamination of the surrounding area of waterwheel engine.

3- Increased the keep period of some grains for domestic use all year without using pesticides.

\section{MATERIAL AND METHODS}

Short grains of, cowpea (karem8) and beans (Geza 3) grown in experimental farm of agriculture search station were harvested using manual method at about (18.7 and $20.5 \%)$ moisture content. The samples were stored temporarily in store room at $297-301 \mathrm{k}^{\mathrm{o}}\left(24-28 \mathrm{C}^{\mathrm{o}}\right)$ to prevent any moisture loss and minimize quality changes before each experiment, rough samples were taken out from the stored room and leaved at the ambient temperature until the initial temperature of the grains approached an equal level to the ambient temperature. The weight sample that used to roasting was $10 \mathrm{~kg}$.

1. Power source of waterwheel: Diesel engine type dewets with a brake horsepower $16 \mathrm{hp}(11.9 \mathrm{~kW})$, single cylinder, and water-cooling; with a total mass of $355 \mathrm{~kg}$, capacity of fuel tank 24 liter. The average specific fuel consumption (SFC) according to the manufacture manual was 475 g/kW.h.

2. Transmission system of water wheel: Figure 1 indicated that the transmission system of waterwheel, gearbox consists of six gears and two pulleys, the first pulley connected with engine by diameter $105 \mathrm{~mm}$ and the second pulley connected with gearbox by diameter $1000 \mathrm{~mm}$., made in England and type was sharmis.

3. Transmission system of roasting unit: The transmission system of roasting unit was two pulleys; the diameters were (150 and $94 \mathrm{~mm})$ the first pulley connected with the transmission system of waterwheel and the second connected with roasting unit. To turn the motion from horizontal to vertical used corona. 
4. Roasting unit: Manufactory local unit and the classification were; weight $53 \mathrm{~kg}$, external diameter $400 \mathrm{~mm}$, thickness $50 \mathrm{~mm}$, and depth $500 \mathrm{~mm}$. To reduce the pollution rate of exhaust gasses and reduce the temperature to suit the roasting process so, the exhaust pipe connected with a joined pipe length was $500 \mathrm{~mm}$ and then connected to a down room of roasting container.

- The bottom of container: The bottom of roasting container consists of two layers made of metal. The spaces between two layers were variables $(5,10,15,20$ and $25 \mathrm{~cm})$ and this chamber containing on some of the barriers to distribute the exhust gasses in the container bottom as it was out of gass from the opposite side.

5. Petot tube: Used to determine manometer compressor.

6. Determined moisture content: For each treatment, of (beans and cowpea) took manual random samples to determine the moisture content in samples by using apparatus electronic moisture meter. The classification was; Type: GANN Hydromelle G 86, Made in Western Germany.

7. Determined the temperature of sample: The classification of apparatus, which used to determine the temperature degree of sample after different treatments was, Type: Omegatemp, Made in: Germany.

\section{Methods of evaluation.}

The discharge and efficiency used to evaluate waterwheel. Distribution temperature and quantity of heat in grains, moisture content in sample, grain crack percentage, discoloration rate, the weight rate of carbon element, energy requirements and costs rats were using to evaluate the roasting method.

1. Determined the discharge for waterwheel (by used quantity of water in channel): The discharge of waterwheel was calculating as using the following equation; (Manning eq.).

$\mathrm{Q}=\mathrm{A} \times \mathrm{V}$

Whereas; $\quad V=\frac{R^{2 / 3} \times S^{1 / 2}}{n}$ and $\quad R=\frac{A}{P}$

$\mathrm{Q}=$ Discharge, $\mathrm{m}^{3}$ /sec., $\mathrm{R}=$ Radius half diameter hydraulic, $\mathrm{A}=$ Area of the discharge $\mathrm{m}^{2}, \mathrm{~V}=$ Velocity of flowed water, $\mathrm{m} / \mathrm{sec}$., $\mathrm{P}=$ Wettable of 
circumference, $\mathrm{m}$ $\mathrm{n}=$ Factor $(0.012-0.016), \mathrm{S}=$ Slip of watercourse, $\mathrm{m}$.

2. Pump Efficiency: The pump efficiency was calculating as using the following equation;

$\zeta_{p}=\frac{W}{B}$

Whereas; $\zeta p=$ Pump efficiency, $\mathrm{B}=$ Brake horsepower. While the water power was calculated as using the following equation;

$W(h p)=9.81 \frac{Q \times h}{270}$

Whereas; $\mathrm{Q}=$ Discharge, $\mathrm{m}^{3} / \mathrm{sec}$., $\mathrm{h}=$ Hydraulic pressure.
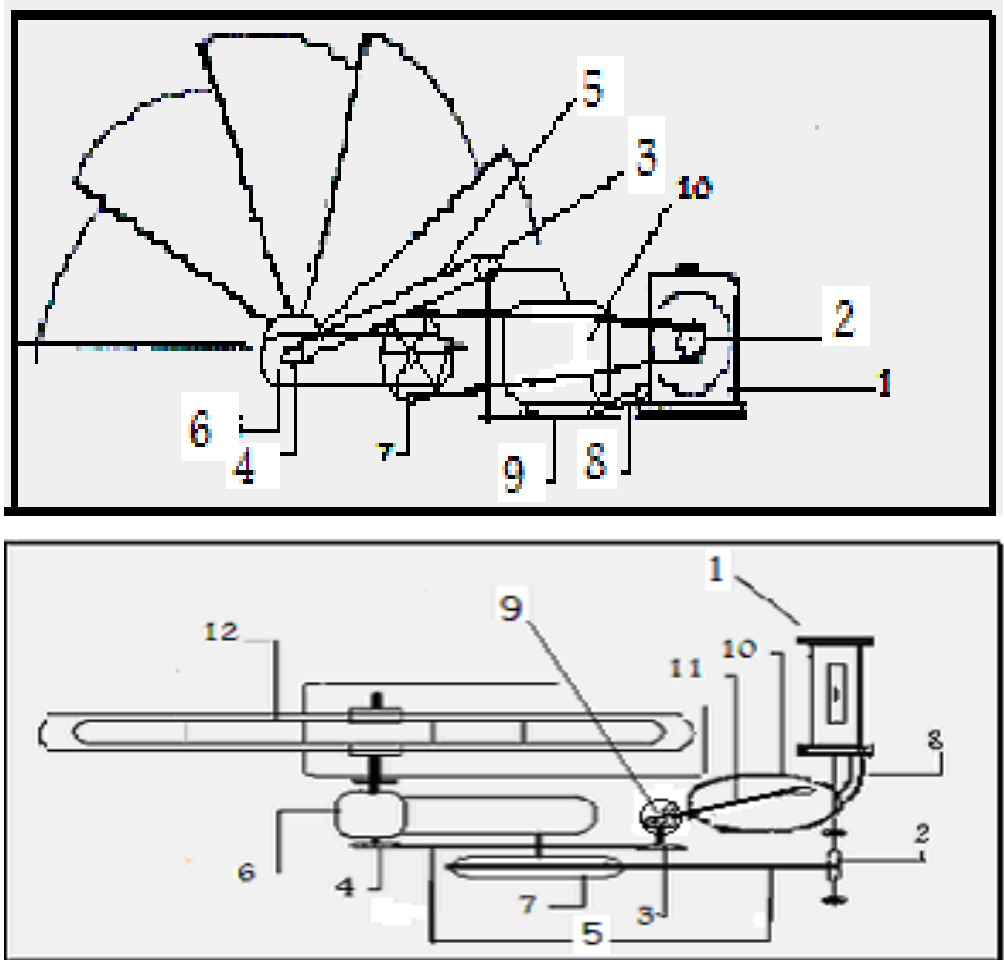
1- Engine
2- Pully waterwheel $(105 \mathrm{~mm})$
3- Pully roasting $(94 \mathrm{~mm})$
4- Pully roasting $(150 \mathrm{~mm})$
5- Blates
6- Gear box

7- pully waterwheel $(1000 \mathrm{~mm})$

8 -Exhusting tube

9- Corona

10-Container roasting

11-Turnning arm

12-Waterwheel sakia 
Fig. 1. The lay out of waterwheel with roasting unit

3. Distribution and quantity own heat: Determined the rate of conduction heat transfer by using following equation;

$q=-\frac{k A \Delta T}{L}$

$\mathrm{q}=$ Rate of conduction heat transfer, $\mathrm{kJ} / \mathrm{s}, \mathrm{k}=$ Coefficient of thermal conductivity, $\mathrm{A}=$ Surface area, $\mathrm{m}^{2}$ $\Delta \mathrm{T}=$ Difference temperature degrees difference on the surface vessel and $\mathrm{L}=$ Wall thickness, $\mathrm{m}$

b. The quantity of heat: To calculate the quantity own heat of grains by using the following equation;

$q=\frac{m \times c \times \Delta t}{T}$

$\mathrm{q}=$ The quantity own heat for grains, $\mathrm{kJ} / \mathrm{sec}$., $\mathrm{c}=$ Specific heat for grains $\mathrm{kJ} / \mathrm{kg} . \mathrm{k}^{\mathrm{o}}, \mathrm{T}=$ Time of roasting, sec., $\Delta \mathrm{t}=$ Difference temperature degree, $\mathrm{k}^{\mathrm{O}}$.

4. Grain crack percentage: For each treatment, a total of 100 grains of (beans and cowpea) were taking manual random samples and determined the number of cracked kernels. The cracked grains were calculating as a percentage using the following equation;

Crackedgrains, $\%=\frac{N_{1}}{N_{2}} \times 100$

$\mathrm{N}_{1}=$ Number of cracked kernels, $\mathrm{N}_{2}=$ Total number of sample.

5. Discoloration rate: For each treatment, a total of 100 grains of (beans and cowpea) were taking manual random samples and determined the number of discolor grains after six month. The discolor grains were calculated as a percentage using the following equation;

Discolorationrate, $\%=\frac{g_{1}}{g_{2}} \times 100$

$\mathrm{g}_{1}=$ Number of discolor grains, $\mathrm{g}_{2}=$ Total number of sample

6. The weight rate of carbon element: To determine the weight rate of carbon element which sediment on the barriers from passage exhausting 
gasses. By putting aluminum papers on barriers for one hour and then determine the weight papers after and before experiment.

7. Energy requirements: Energy requirements estimate by the following equation;

$$
\mathrm{EP}=\mathrm{FC}\left(\frac{1}{3600}\right) \mathrm{PE} \times \mathrm{LCV} \times 427 \times \eta_{\mathrm{thb}} \times \zeta_{\mathrm{m}^{---}}(7)
$$

Whereas; $\mathrm{FC}=$ The fuel consumption, $\mathrm{L} / \mathrm{h}, \mathrm{PE}=$ The density of fuel $\mathrm{kg} / \mathrm{L}$, for solar $=0.85, \mathrm{LCV}=$ The lower calorific value a fuel, average of fuel is $10000 \mathrm{k} \mathrm{cal} / \mathrm{kg}, \mathrm{y}_{\mathrm{thb}}=$ The thermal efficiency of engine, $40 \%$ for diesel engine, 427= Thermo-mechanical equivalent and $\zeta \mathrm{m}=$ The mechanical efficiency of engine, $80 \%$ for diesel engine.

8. Cost estimation: The following equation of Awady, 1978 was taking into account to the cost per hour for two different types.

$$
C=\frac{P}{h}\left(\frac{1}{L}+\frac{i}{2}+a+r\right)+(0.9 W \times F \times U)+b^{-------~}
$$

Whereas; $\mathrm{C}=$ Cost per hour of operation. L.E/h, $\mathrm{P}=$ Estimated price of the machine L. E., h = Estimated yearly hours operation, $450 \mathrm{~h}, \mathrm{~L}=$ Life expectancy of the machine, 10 years, $\mathrm{i}=$ Annual interest rate, $10 \%, \mathrm{a}=$ Annual taxes and overheads, $2 \%, \mathrm{r}=$ Annual repair and maintenance rate, $18 \%, 0.9=\mathrm{A}$ correction factor for rated load ratio and lubrication, $\mathrm{w}=$ Engine power, hp.

$\mathrm{F}=$ Specific fuel consumption L/hp.h, $\mathrm{U}=$ Fuel price L.E $/ \mathrm{L}$ and $\mathrm{b}=$ Hourly labor wage L.E/h.

\section{RESULTS AND DISCUSSION}

The experiments were carrying out on three stages. The first stage includes the performance of the waterwheel engine after and before connected roasting unit with it. The second stage determined the relationship between the high of the container bottom, which receives the exhaust gasses, and the heat gained for seeds and determines the best rotation speed for turnning arm. The third stage determined the effect of these treatments on discolor rate of grains after six month. 


\section{The performance of the waterwheel after and before connected roasting unit with it.}

Table 1 showed that the effect of connected roasting unit on waterwheel discharge. The discharge of waterwheel was decreasing by average $0.002 \mathrm{~m}^{3} / \mathrm{sec}$. This value was little and does not large effect on total discharge of waterwheel.

Table 1. The rate of waterwheel discharge after and before connected roasting unit with it.

\begin{tabular}{||l||l|l||}
\hline Type system & Waterwheel only & Waterwheel with roasting \\
\hline \hline Discharge, $\mathrm{m}^{3} / \mathrm{sec}$. & 0.233 & 0.231 \\
\hline \hline $\mathrm{W}($ Water power, $\mathrm{hp})$ & 2.86 & 2.84 \\
\hline \hline$\zeta \mathrm{p}($ pump efficiency) & 34 & 33.52 \\
\hline
\end{tabular}

2. The relation between rising temperature of roasting container and high lower surface of roasting container.

By increasing the space between two lower layer surface of container by $5 \mathrm{~cm}$, the temperature of rosting container drop by average $7.9^{0}$ with the sability of time element. This was due to the loosing rate of heat to the space. These results were illustrating in table 2.

Table. 2. The relation between rising temperature of roasting container unit and height lower surface of roasting container.

\begin{tabular}{|c|c|}
\hline $\begin{array}{c}\text { The height between two layers } \\
\text { of container lower surface, } \mathrm{cm}\end{array}$ & $\begin{array}{c}\text { The rate raise temperature of } \\
\text { the roasting container, } \mathrm{k}^{0}\end{array}$ \\
\hline \hline 5 & 319.7 \\
\hline 10 & 312.3 \\
\hline \hline 15 & 304.4 \\
\hline \hline 20 & 298.7 \\
\hline \hline 25 & 292.4 \\
\hline \hline
\end{tabular}




\section{The relation between roasting temperature and grains temperature.}

When the roasting temperature increased by average $6.9^{0}$ the grains temperature increased by average $3.8^{\circ}$ and $2.3^{\circ}$ for cowpea and beans grains respectively. However, the roasting time increased by $5 \mathrm{~min}$. the grains temperature increased by average $12.5^{\circ}$ and $10.4^{\circ}$ for cowpea and beans grains respectively. These data were showing in figure 2 .

4. The relation between roasting time and roasting tempeture on quantity own heat of grains and the type of distribution heat transfer from container.

When the roasting temperature increased by average $6.9^{0}$ the quantity own heat increased by average 0.047 and $0.036 \mathrm{~kJ} / \mathrm{sec}$. for cowpea and beans grains respectively. However, the roasting time increased by $5 \mathrm{~min}$. the quantity own heat increased by average 0.15 and $0.13 \mathrm{~kJ} / \mathrm{sec}$ for cowpea and beans grains respectively.The roasting unit depended on transmit heat by conduction, the total amount of heat was $3.76 \mathrm{~kJ} / \mathrm{sec}$. this value was enough to roasting processes under different treatments. These data were showing in figure 3.

\section{The relation between roasting time and roasting temperature on moisture content of grains.}

The effects of different roasting temperature on grains moisture content were showing in figures 4 and 5 . These figures showed that by increasing the roasting temperature by average $6.9^{0}$ the moisture content of cowpea and beans grains were decreasing by average 1.8 and $1.1 \%$ respectively. However, the time roasting increased by $5 \mathrm{~min}$ the moisture content was decreasing by average 2.8 and $2.3 \%$ for cowpea and beans grains respectively.

\section{The relation between revolution speeds of turning arm and grains broken percent.}

As shown in the figure 6, the grains broken percentage was varying for different revolution speeds of the turning arm. In addition that, by increasing revolution speed of turning arm the grains broken increased by average $16 \%$ and $10.5 \%$ for cowpea and beans grains. The suitable revolution speed of turning arm was $8 \mathrm{rpm}$ for cowpea grains and 8 to 10 rpm for beans grains. 

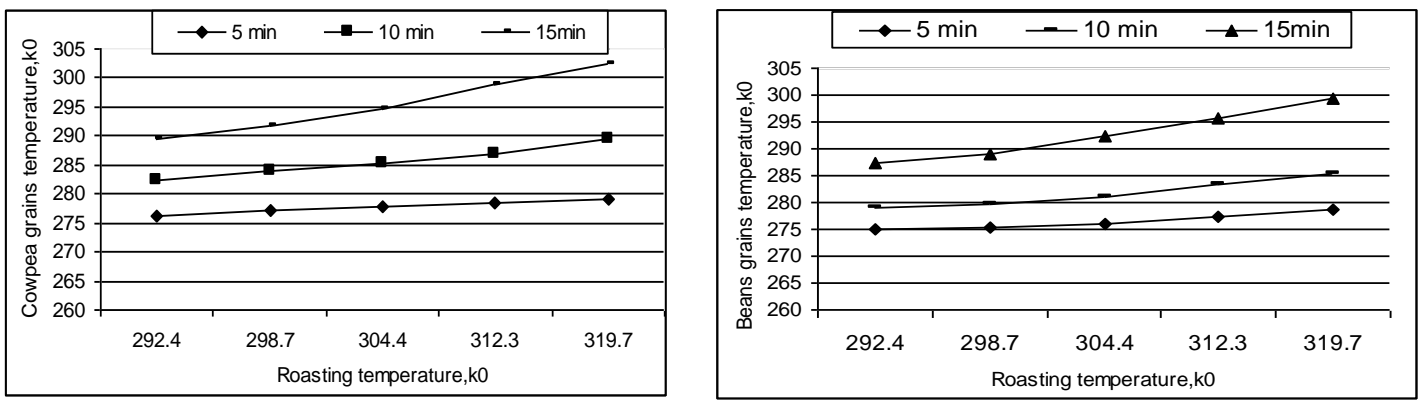

Fig.2. The relation between roasting temperature and grains temperature.
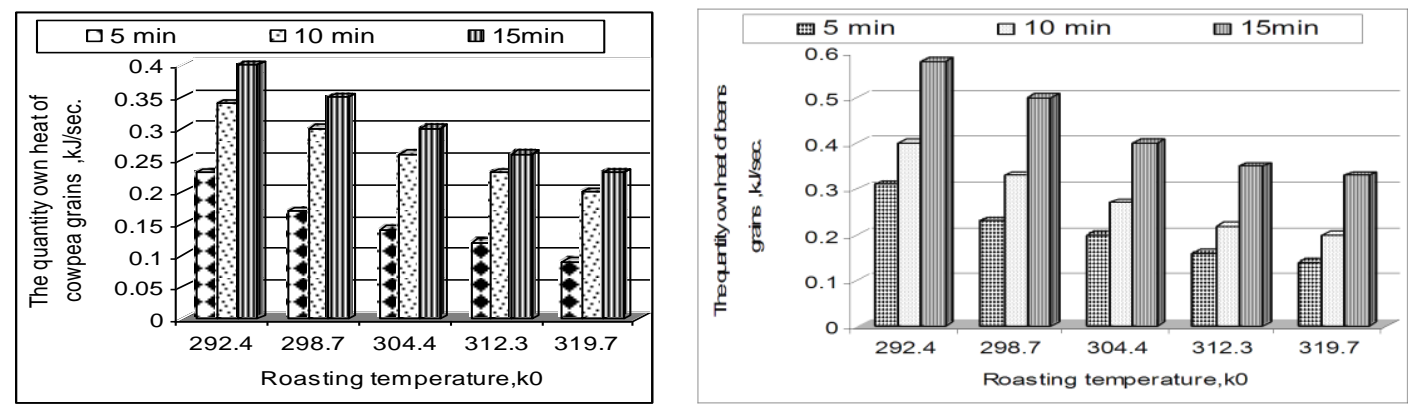

Fig.3. The relation between roasting time and roasting tempeture on quantity own heat of grains.

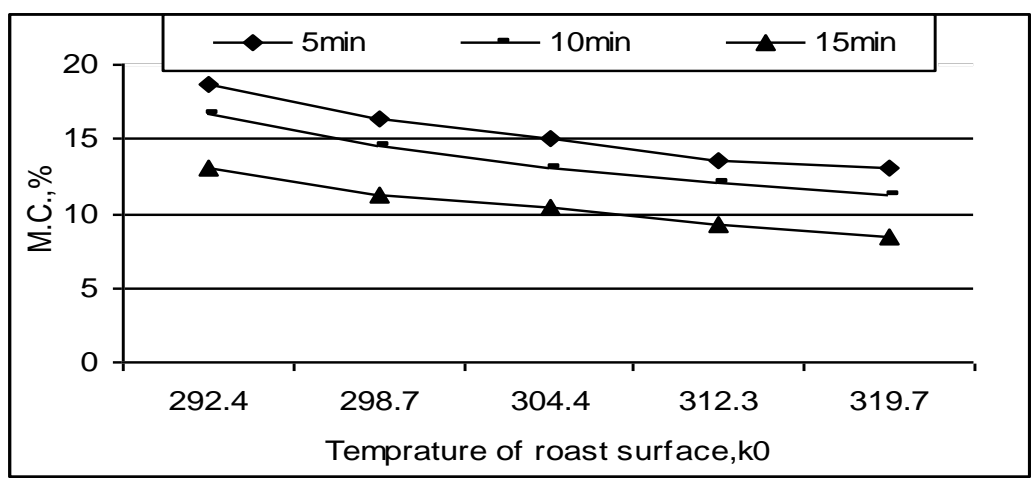

Fig. 4. The relation between roasting temperature, $\mathrm{k}^{0}$ and moisture content, $\%$ of cowpea grains. 


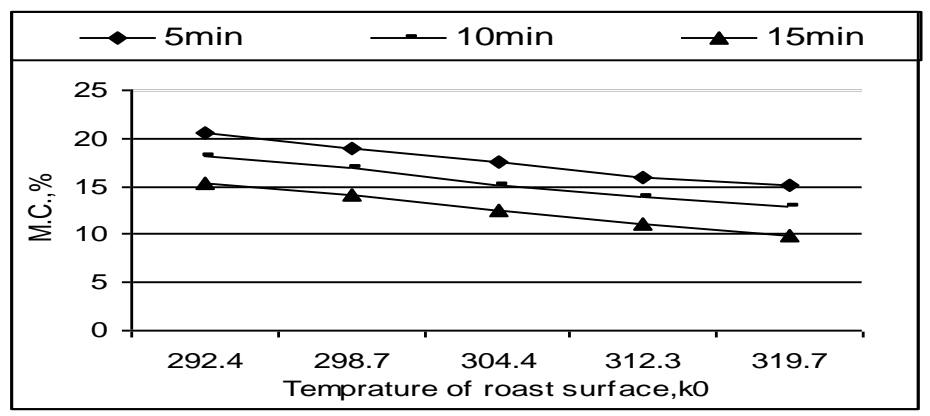

Fig. 5. The relation between roasting temperature, $\mathrm{k}^{0}$ and moisture content, $\%$ of beans grains.

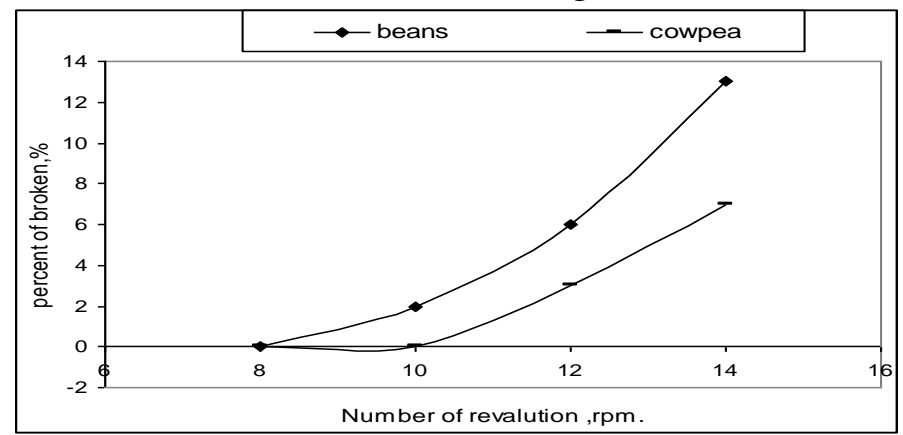

Fig.6. The relation between revolution speed of the turning arm and the rate broken grains.

\section{The relation between raise temperature and discoloration rate of grains under different treatments.}

The samples were stored for six months then had opened and recorded the percentage of discolors grains. These data illustrated in figure 7 . These figures showed that, there was no discolor rate in cowpea grains by using roasting temperature 312.7 to $304.4 \mathrm{k}^{0}$ with roasting time 10 to 15 min. under moisture content $10 . r \%$ and $9.3 \%$ but, when these grains exposed to $319.7 \mathrm{k}^{0}$ gave heavy dark grains. While the suitable roasting temperature for bean grains was 312.7 to $304.4 \mathrm{k}^{0}$ and roasting time 15 min. under moisture content $12 \%$ to $10.5 \%$ at the same speed revolution $8 \mathrm{rpm}$. However, these grains exposed to $319.7 \mathrm{k}^{0}$ with roasting time 10 to $15 \mathrm{~min}$. gave little dark grains. The discoloring rate of the compare sample, which was taking out from pockets and leaved at the ambient temperature until the initial temperature of the grains, approached an equal level to the ambient temperature was $100 \%$ for beans and cowpea. This was due to the suitable temperature and moisture content to grow store insects. 


\section{The weight rate of carbon element.}

The weight rate of carbon element which sediment on the barriers by passages exhausting gasses was $5.5 \times 10^{-4} \mathrm{~g} / \mathrm{sec}$. so this method reduces the rate of contamination of the area, which surrounded the waterwheel power.

\section{Energy Requirements.}

The energy requirement for waterwheel only was $4.3 \mathrm{~kW} . \mathrm{h}$ (energy by area was $2.16 \mathrm{~kW} . \mathrm{h} / \mathrm{fed}$ ) and roasting unit only was $3.3 \mathrm{~kW}$.h (energy by ton was $19.41 \mathrm{~kW} . \mathrm{h} /$ ton) But by using waterwheel with roasting unit was $4.6 \mathrm{~kW}$.h. This energy was dividing to $4.3 \mathrm{~kW}$.h. for waterwheel and 0.3 $\mathrm{kW}$.h. for roasting process instead of $3.3 \mathrm{~kW} . \mathrm{h}$. These data illustrated that by using waterwheel and roasting unit saves the energy requirements by $83.11 \%$. These data was showing in figure 8 .

\section{Machinery Cost Estimation.}

Figure 9 showed that the total cost for waterwheel only was $4.01 \mathrm{LE} / \mathrm{h}$ (2.05 LE/fed) and the cost for roasting unit only was 3.9LE/h (22.94 LE /ton). While the total costs for waterwheel with roasting unit were 4.5 $\mathrm{LE} / \mathrm{h}$., these costs divided to $4.01 \mathrm{LE} / \mathrm{h}$ for waterwheel and $0.49 \mathrm{LE} / \mathrm{h}$ (2.88 LE/ton) for roasting unit. Therefore, the using roasting unit with waterwheel saves the costs by average $78 \%$ these results illustrated that by using waterwheel with roasting unit save the costs by average 3.41 LE/h (20.06 LE /ton).

\section{CONCLUSIONS.}

The discharge of waterwheel, which attached with roasting decreased by $0.002 \mathrm{~m}^{3} / \mathrm{sec}$ compared with the discharge of waterwheel only. The roasting unit depended on transmit heat by conduction. There was no discolor rate in cowpea grains by using roasting temperature 312.7 to $304.4 \mathrm{k}^{0}$ with roasting time 10 to $15 \mathrm{~min}$. under moisture content $10.2 \%$ and $9.3 \%$.While the suitable roasting temperature for bean grains was 312.7 to $304.4 \mathrm{k}^{0}$ and roasting time $15 \mathrm{~min}$. under moisture content $12 \%$ to $10.5 \%$ at the same speed revolution $8 \mathrm{rpm}$. The energy requirement for waterwheel and roasting was $4.4 \mathrm{~kW}$. Overall, the data illustrated that by using waterwheel and roasting save the energy by average $83.11 \%$ and the costs by average $78 \%$. 

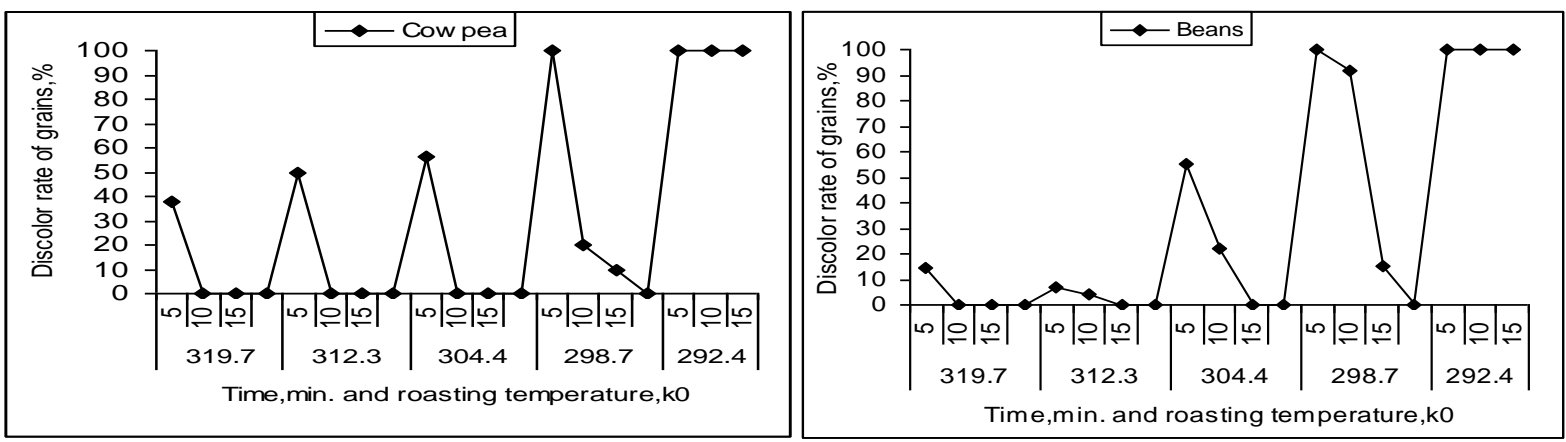

Fig.7. The relation between discolor rate of grains and roasting temperature.

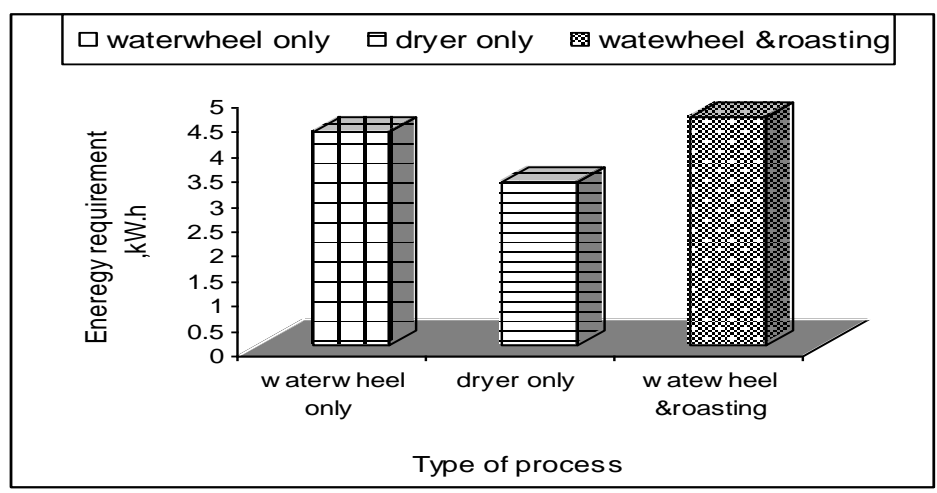

Fig. 8. The relation between process type and energy requirement, kW.h

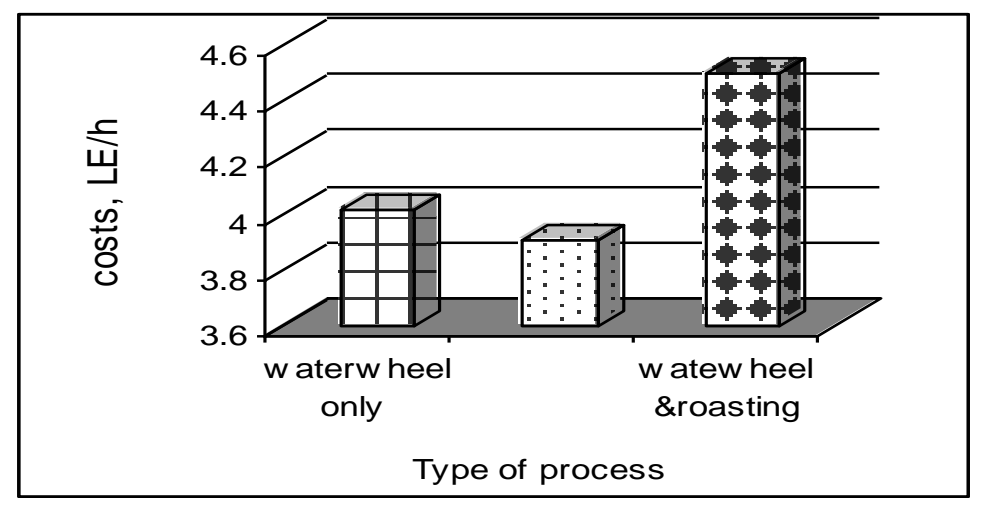

Fig.9. The relation between process type and costs LE/h. 


\section{REFERENCES.}

Awady, M. N. (1978): "Engineering of tractors and agricultural Machinery" (Arabic) Textbook. Agric, Ean shams univ: 289.

Bruce D.M.,1992 . A model of the effect of heated-air roasting on the bread baking quality of wheat. J. Agric.Eng. Res. Vol 52 (5): 3551

El-Awad,-M and R-Stillwater, 1991. "Discharge and mechanical efficiency of Egyptian waterwheels.Dep. Civil and Agric. Engineering, Univ. Melbourne, Parkville, Victoria, Australia. Agricultural-Water- anagement. 1991; 20(2): 135-153.

Irtwange S. V. and J.C. Igbeka, 2002. Effect of moisture contant and power input on thermal conductivity of African yam beans (Sphenostylis Stenocarpa) . Transaction of ASAE. Vol. 45(5):14751478 .

Mousa, E.A.E., Elham, A.E. and Abelatif E.A.,1998. contamination of roadside soil and plant with lead from automotive exhaust Gasses. Zagazig J. Agric. Res.,Vol.25(5):851 - 860.

Ruf,-T, 1996. "The fellah's participation in irrigated agriculture in modern Egypt Sustainability - of - irrigated -agriculturefarmers' articipation - towards sustainable - agric-ulture: volume 1-B- Trans-actions - of-the- 16th- Inter-national - Congress - on Irrigation - and Drainage,-Cairo, - Egypt,-1996. 1996; 427-437

Shrein F. A., Kadry, M.A.., and El Said, J.H., 2008. Development power supply of the Egyptian waterwheel. Zagazig J. Agric. Res.,Vol.35(5):1213 - 1229

Yang W., S. Sokhanssanj, L.Jr.Tabil, J. Tang and S. Yannacopulos,1997. specific heat measurement for borage seeds by differential scanning calormetery. Journal food Processing and preservation 21, 395-407. 
Zaghloul A. O. and A. K. Mourad, 1996. studies on he use of ash for protection of stored cowpea seeds callosobruchus maculates (F.) (coleopteran: bruchidae) Zagazig J. Agric. Res. Vol. 23(5): 465478.

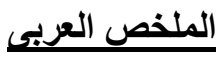

\section{معظمة الإستفادة من وحدة إدارة المياة \\ شرين فؤاد عبدالحميد محمد*}

من منطلق تفاعل البحث العلمى مع البيئة ودور البحث العلمى فى خدمة المجتمع تم التعرف على العى العي

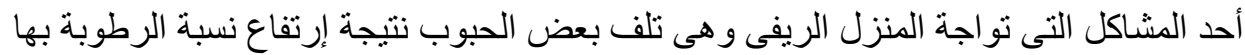

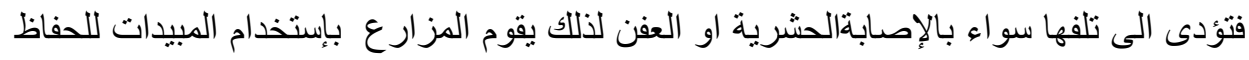

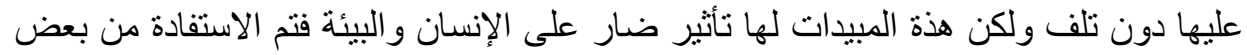

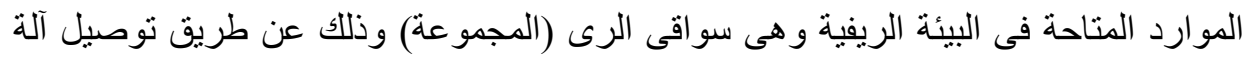

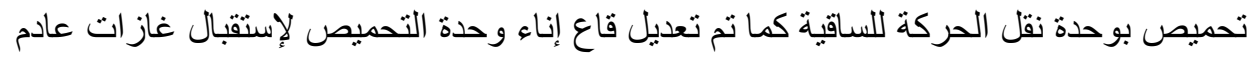
المحرك كمصدر حرارى لجهاز التحميص.

$$
\text { الهزف من البحث: }
$$

$$
\text { ا ـ يهدف البحث الى زيادة كفاءة محركات الرى فى السواقى المصرية }
$$

r ـ التقليل من معدل تلوث المساحة المحيطة بمحرك الساقية بغاز ات العادم ؟ـ زيادة مدة حفظ

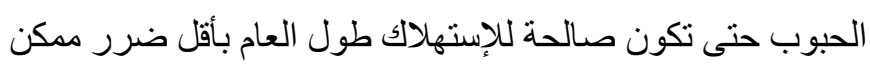

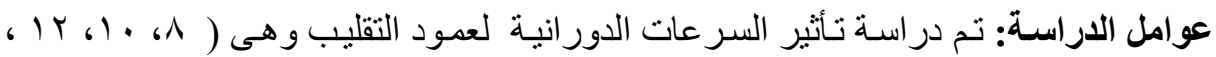

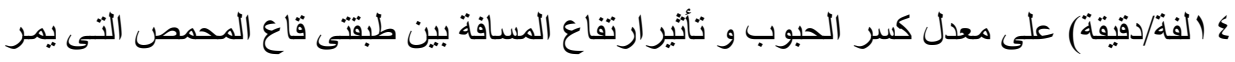

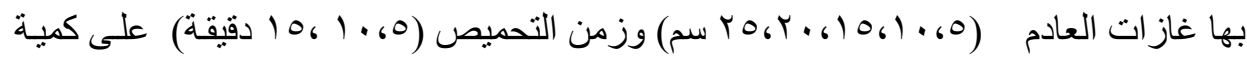

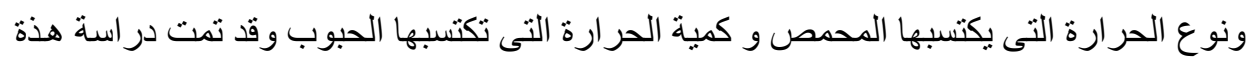

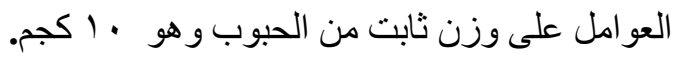

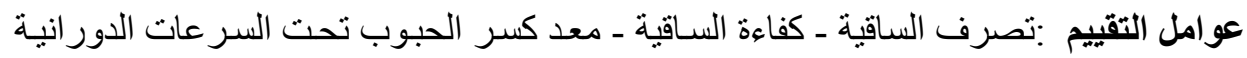

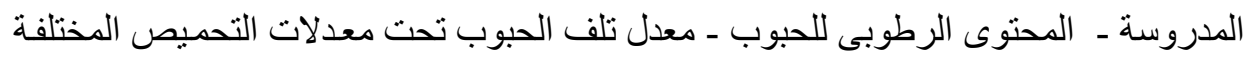

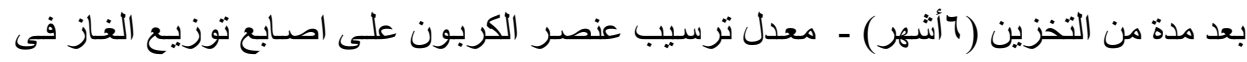

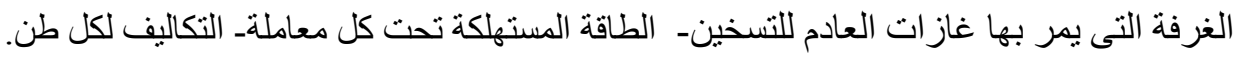

* قسم ميكنة المحاصيل الحقلية والبستانية ـ معهز بحوث الهندة الزراعيةـ الاقى الجيزة ـ مصر. 


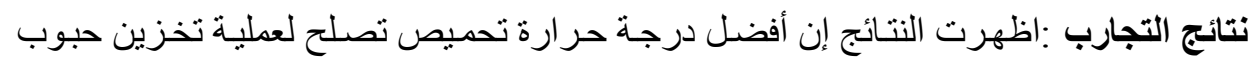

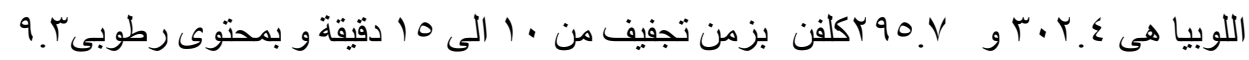

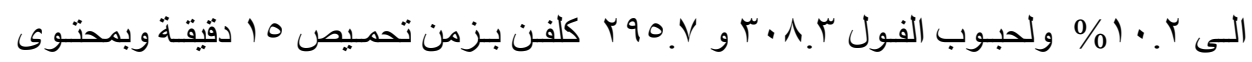

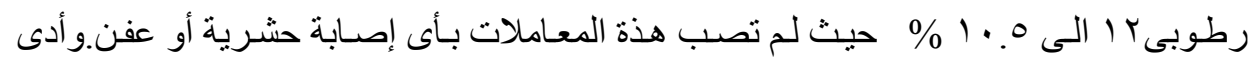

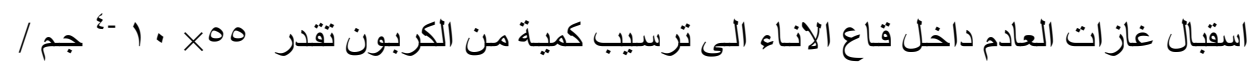

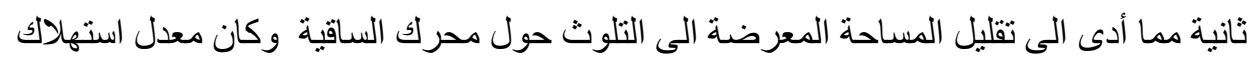

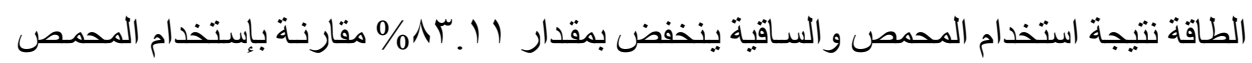

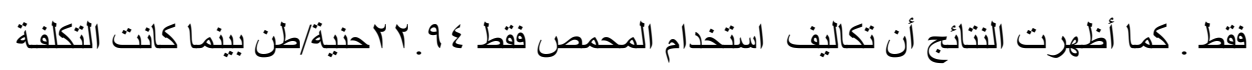

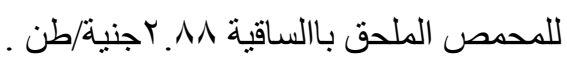

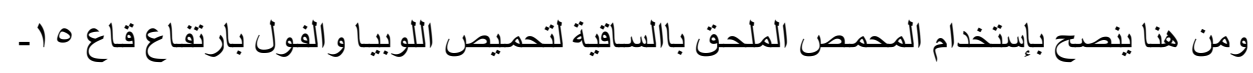

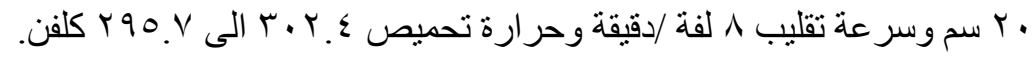

